\title{
Enhanced tolerance to Phytophthora root and stem rot by over-expression of the plant antimicrobial peptide CaAMP1 gene in soybean
}

Lu Niu ${ }^{1 \dagger}$, Xiaofang Zhong ${ }^{1+}$, Yuanyu Zhang ${ }^{1}$, Jing Yang ${ }^{1}$, Guojie Xing ${ }^{1}$, Haiyun Li ${ }^{1}$, Dongbo Liu ${ }^{1,2}$, Rui Ma ${ }^{1}$, Yingshan Dong ${ }^{1 *}$ and Xiangdong Yang ${ }^{1 *}$ (D)

\begin{abstract}
Background: Antimicrobial peptides play important roles in both plant and animal defense systems. Moreover, over-expression of CaAMP1 (Capsicum annuum antimicrobial protein 1), an antimicrobial protein gene isolated from C. annuum leaves infected with Xanthomonas campestris pv. vesicatoria, confers broad-spectrum resistance to hemibiotrophic bacterial and necrotrophic fungal pathogens in Arabidopsis. Phytophthora root and stem rot (PRR), caused by the fungus Phytophthora sojae, is one of the most devastating diseases affecting soybean (Glycine max) production worldwide.

Results: In this study, CAAMP1 was transformed into soybean by Agrobacterium-mediated genetic transformation. Integration of the foreign gene in the genome of transgenic soybean plants and its expression at the translation level were verified by Southern and western blot analyses, respectively. CaAMP1 over-expression (CaAMP1-OX) lines inoculated with $P$. sojae race 1 exhibited enhanced and stable PRR tolerance through $\mathrm{T}_{2}-\mathrm{T}_{4}$ generations compared with the wild-type Williams 82 plants. Gene expression analyses in the transgenic plants revealed that the expression of salicylic acid-dependent, jasmonic acid-dependent, and plant disease resistance genes (R-genes) were significantly up-regulated after $P$. sojae inoculation.

Conclusions: These results indicate that CaAMP1 over-expression can significantly enhance PRR tolerance in soybean by eliciting resistance responses mediated by multiple defense signaling pathways. This provides an alternative approach for developing soybean varieties with improved tolerance against soil-borne pathogenic PRR.
\end{abstract}

Keywords: CaAMP1, Transgenic soybean, PRR tolerance, Antimicrobial peptide

\section{Background}

More than 8000 antimicrobial peptides (AMPs), representing key components of the innate immune system in both plants and animals, have been isolated from amphibians, mammals, plants, bacteria, and insects [1].

\footnotetext{
*Correspondence: yingshandong@hotmail.com; xdyang020918@126.com

${ }^{\dagger}$ Lu Niu and Xiaofang Zhong contributed equally to this work.

${ }^{1}$ Jilin Provincial Key Laboratory of Agricultural Biotechnology, Jilin Academy of Agricultural Sciences, Changchun 130033, China

Full list of author information is available at the end of the article
}

Plant AMPs are expressed in roots, stems, leaves, flowers and seeds, and inactivate prokaryotic cells by targeting several essential metabolic processes at extracellular and intracellular sites and the plasma membrane [2]. AMPs are known to play important roles in constitutive or induced resistance to various pathogens, by degrading fungal cell walls, inducing membrane channel and pore formation, inhibiting DNA synthesis and cell cycle, and damaging cellular ribosomes [3-7]. Plant AMPs have

(c) The Author(s). 2020 Open Access This article is licensed under a Creative Commons Attribution 4.0 International License, which permits use, sharing, adaptation, distribution and reproduction in any medium or format, as long as you give appropriate credit to the original author(s) and the source, provide a link to the Creative Commons licence, and indicate if changes were made. The images or other third party material in this article are included in the article's Creative Commons licence, unless indicated otherwise in a credit line to the material. If material is not included in the article's Creative Commons licence and your intended use is not permitted by statutory regulation or exceeds the permitted use, you will need to obtain permission directly from the copyright holder. To view a copy of this licence, visit http://creativecommons.org/licenses/by/4.0/ The Creative Commons Public Domain Dedication waiver (http://creativecommons.org/publicdomain/zero/1.0/) applies to the data made available in this article, unless otherwise stated in a credit line to the data. 
been shown to enhance tolerance to many fungal diseases in several species, including pepper [8], rice [7, 9, 10], potato [11], tobacco [3], and creeping bentgrass and citrus [12, 13]. In addition, a defensin from chickpea, which is a type of AMP, confers tolerance against water deficit stress in Arabidopsis thaliana [14].

CaAMP1, an AMP gene isolated from pepper (C. annuиm) leaves infected with Xanthomonas campestris pv. vesicatoria, has been implicated in broad-spectrum resistance to the hemibiotrophic bacterial pathogen Pseudomonas syringae pv. tomato, biotrophic oomycete Hyaloperonospora parasitica, and fungal necrotrophic pathogens Fusarium oxysporum f. sp. matthiolae and Alternaria brassicicola [8]. Over-expression of CaAMP1 enhances tolerance to hemibiotrophic bacterial and necrotrophic fungal pathogens in Arabidopsis, when compared with the wild-type plants, and induces two salicylic acid (SA) pathway-dependent genes, i.e., PR1 (PATHOGENESIS-RELATED) and PR5 expression [8]. Defensin genes isolated from rice (OsDEF7 and OsDEF8) have been shown to inhibit the phytopathogens $X$. campestris pv. glycines, X. oryzae pv. oryzicola, and Erwinia carotovora subsp. atroseptica, and weaken the activity of the phytopathogenic fungi Helminthosporium oryzae and F. oxysporum f. sp. cubense [7, 9]. Protein extracts with MSI-99, an AMP expressed in chloroplasts of tobacco, could significantly suppress two rice blast isolates, both in vitro and in vivo [10]. Furthermore, leaf extracts from transplastomic tobacco are shown to inhibit the growth of pregerminated spores of three fungal species, Aspergillus flavus, F. moniliforme, and Verticillium dahliae [3], whereas expression of the AMP alfAFP in transgenic greenhouse-grown potato confers tolerance against $V$. dahliae, an agronomically important fungal pathogen [11]. In addition, AMPs have also been demonstrated to enhance tolerance to fungal diseases in bentgrass and citrus [12, 13]. Collectively, these findings evidence that AMPs play key roles in plant defense against fungal pathogens, and that over-expression of these peptides can enhance tolerance against many fungal diseases.

Soybean (Glycine max L. Merr.) is an economically important crop worldwide, acting as a rich source of vegetable oil and protein for both humans and livestock. Phytophthora stem and root rot (PRR), caused by the soil-borne hemibiotrophic oomycete Phytophthora sojae, is one of the most devastating fungal diseases in soybean, resulting in an annual yield reduction and economic loss of approximately $10-50 \%$ and $1-2$ billion dollars, respectively [15-18]. PRR caused by $P$. sojae has become a major threat to soybean production in China since it was first reported in 1989 [15, 19]. Current measures for controlling PRR in the fields include drainage improvement, crop rotation, and fungicide application. Host-mediated resistance provided by "resistant to $P$. sojae" (Rps) genes has also been employed to improve PRR tolerance in soybean [16, 20-25]. However, Rpsmediated resistance to PRR in soybean may be lost over long periods owing to the high variability of $P$. sojae, with at least 55 races identified to date [26]. Other alternative control methods include the development of transgenic soybean with enhanced PRR tolerance achieved by the increased levels of pathogenesis-related (PR) proteins, such as Gly $\mathrm{m} 4 \mathrm{l}$ and ethylene response factor [27], or harpin protein-encoding genes [28, 29].

As mentioned previously, AMP over-expression confers broad-spectrum resistance against bacterial and fungal pathogenic infections in plants, suggesting that AMPs may enhance soybean resistance to PRR. Therefore, we synthesized CaAMP1 and introduced it into soybean via Agrobacterium-mediated transformation, and then evaluated the tolerance of CaAMP1-OX soybean to PRR. We found that over-expression of CaAMP1 enhanced soybean tolerance to PRR, and induced the expression of genes involved in SA- and JAdependent pathways and $R$-gene signaling.

\section{Results}

\section{Generation and screening of transgenic plants}

The nucleotide sequence of the CaAMP1 (GenBank ID: AAT35532.1) was synthesized and subcloned into a pCambia3300 vector (Fig. 1a). Constitutive expression of CaAMP1 was induced in the soybean plants under the control of CaMV $35 S$ promoter. Constitutive expression was desirable because $P$. sojae can infect soybean at various developmental stages in much of the growing season. Transgenic soybean was generated via Agrobacterium-mediated transformation, with the Williams 82 cultivar as the recipient.

A total of 185 phosphinothricin $N$-acetyltransferase (PAT)-tolerant plants were generated and screened using the LibertyLink strip test, and the positive ones (indicated by two red lines in Fig. 1b) were grown in a greenhouse to produce seeds. Six $\mathrm{T}_{3}$ transgenic soybean lines were selected for PCR and Southern blot analyses. The PCR confirmed that $\mathrm{T}_{3}$ transgenic soybean lines contained CaAMP1 and bar genes (Fig. 1c). Southern blot analysis using CaAMP1 as the probe further confirmed that CaAMP1 was integrated into the genome of transgenic soybean, with approximately 1 to 5 copies of insertions (Fig. 1d). The size of all detected bands was greater than the expected fragment size of $1.98 \mathrm{~kb}$, which covered the sequence between the right border and the unique $E c o$ R I site. In contrast, no signal was detected in the wild-type Williams 82 plants. These results indicated stable integration of CaAMP1 in transgenic soybean.

RT-PCR and western blot analyses were further performed to detect CaAMP1 expression in the six $\mathrm{T}_{3}$ transgenic soybean lines. A 275-bp fragment was 

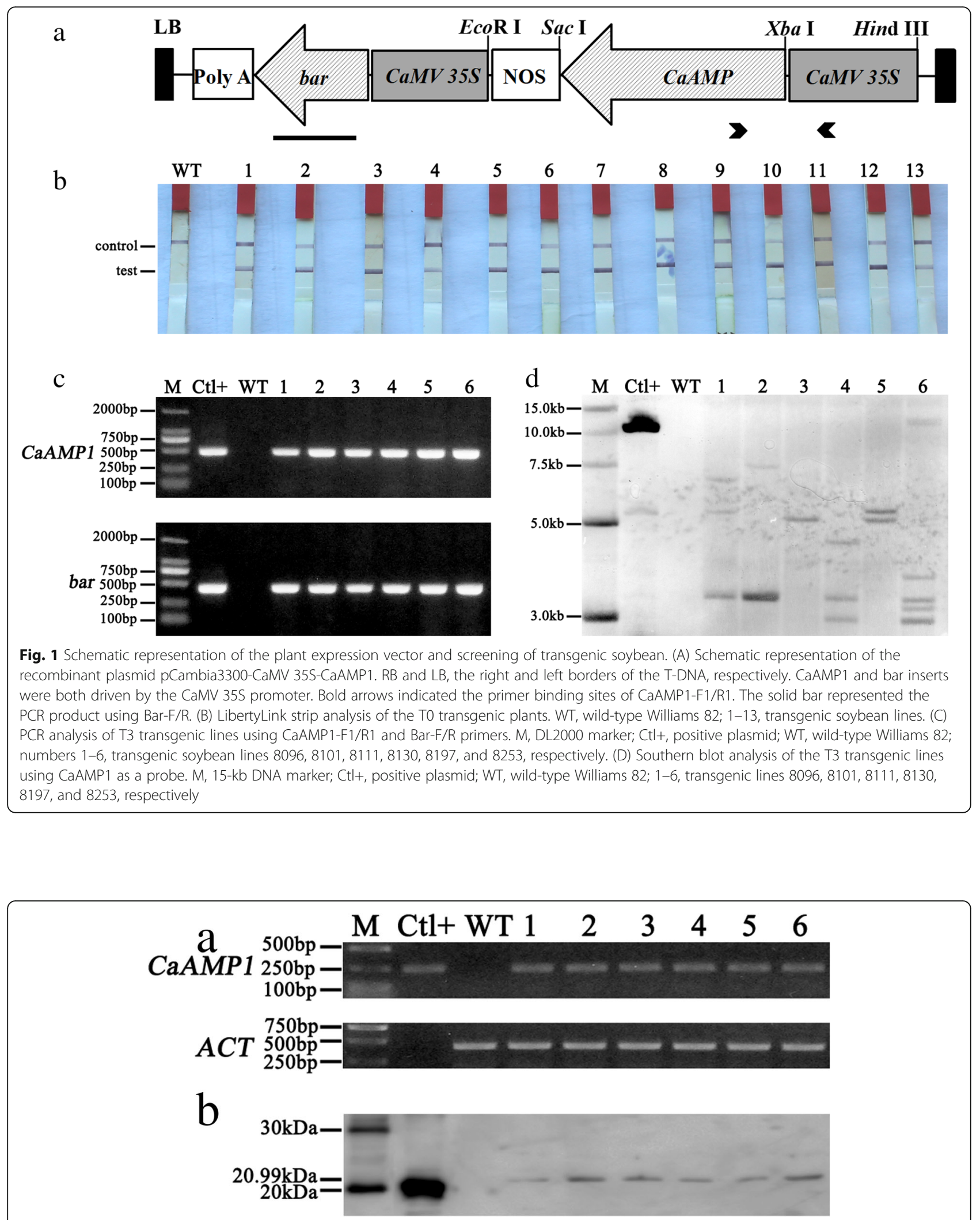

Fig. 2 Analysis of CaAMP1 expression in transgenic soybean lines. (A) RT-PCR analysis of the transgenic lines. (B) Western blot analysis of the transgenic lines. M, DL2000 DNA marker (A) \& protein ladder (B); Ctl+, positive plasmid; WT, wild-type Williams 82; numbers 1-6, T3 transgenic lines $8096,8101,8111,8130,8197$, and 8253 , respectively 
detected in all six transgenic lines by RT-PCR, which was absent from the wild-type Williams 82 (Fig. 2a). We also detected $20.99 \mathrm{kDa}$ bands in the six transgenic lines, which was absent from the wild-type plants, confirming the expression of CaAMP1 at both transcriptional and translational levels in the transgenic soybean (Fig. 2b). These results indicated that $C a A M P 1$ was successfully transformed into the soybean, and accurately transcribed and translated in the six transgenic lines.

\section{Stable and enhanced tolerance of transgenic soybean to PRR}

The PRR tolerance of $T_{3}$ transgenic lines and wild-type soybean was evaluated after inoculation of greenhousegrown plants with $P$. sojae race 1 . As shown in Fig. 3, the tolerance of transgenic lines to PRR was markedly enhanced, when compared with that of the wild-type control and Jiunong 21 (JN21) plants which was susceptible to P. sojae (Fig. 3). Typical symptoms of PRR were visible in wild-type Williams 82 and JN21 5 to 10 days after inoculation with $P$. sojae race 1 mycelia, with some plants succumbing to the progressing pathogenic infection (Fig. 3a), which was more prominent in JN21. In contrast, most transgenic lines were only slightly affected, as evident from the development of chlorotic leaves (Fig. 3a). Survival rates of transgenic lines (66.17$94.68 \%$ ) over three generations were higher than those of wild-type Williams $82(43.67-56.17 \%)$ and JN21 (0$8.08 \%$ ), which was consistent with the results of PRR tolerance (Fig. 3b). Of the six transgenic lines, four (8096, 8101,8197 , and 8253) exhibited a stable enhancement in the tolerance to $P$. sojae race 1 , when compared with the JN21 and wild-type controls (Fig. 3b). In conjunction, these results suggest that CaAMP1-OX transgenic soybean were more tolerant to PRR.

\section{Up-regulation of disease-responsive genes in CaAMP1-OX transgenic soybean}

CaAMP1 has been shown to induce PRs expression in transgenic Arabidopsis [8]. In the present study, the transcription of 15 defense-related genes involved in SAand JA-dependent pathways, and $R$-genes was assessed in two transgenic lines (8096 and 8253) after inoculation with $P$. sojae race 1 . The expression levels of SAdependent pathway genes GmPR1, GmPR2, GmPR3, GmPR5, GmPR12, GmPAL, and GmNPRs, were significantly higher in the two transgenic lines than in the wild-type soybean (Fig. 4a-h). Two JA-dependent pathway genes, GmAOS and GmPPO, also exhibited increased expression in these lines (Fig. 4i and $\mathrm{j}$ ). Moreover, the expression of both $R$-genes, i.e., GmSGT1 and GmRAR1 (Fig. 4k and l), involved in plant resistance to disease, was significantly up-regulated in comparison to the wild-type control. These results indicated that over-expression of the CaAMP1 gene in soybean could elicit multiple resistance responses mediated by different signaling pathways, enhancing plant tolerance against $P$. sojae infection.

\section{No obvious differences in agronomic traits between CaAMP1-OX and wild-type soybean}

To evaluate the effect of over-expression of CaAMP1 in soybean, agronomic traits, including maturity period, leaf shape, flower color, hilum color, plant height, branch number, node number, podding height, and 100-seed weight, of field-grown $T_{3}$ transgenic lines were analyzed. No differences could be detected in these traits between the transgenic lines and wild-type Williams 82 (Table 1). These results indicated that CaAMP1 over-expression conferred transgenic soybean with enhanced and stable tolerance to PRR without any negative effects on its agronomic traits.

Data on the agronomic traits of wild-type Williams 82 and the six transgenic lines (8096, 8101, 8111, 8130, $8197,8253)$ were collected from the experimental station at Gongzhuling, Jilin Province, China. Twenty plants of each line were randomly selected for the measurements. Differences were considered significant at $P<0.05$.

\section{Discussion}

PRR is one of the most devastating diseases in soybean, resulting in annual losses of 1-2 billion dollars worldwide $[15,16]$. Previous studies have confirmed that exogenous resistant genes can enhance PRR tolerance in soybean $[28,29]$. In the present, an AMP gene, CaAMP1, which has previously been demonstrated to confer broad-spectrum resistance against hemibiotrophic bacterial and necrotrophic fungal pathogens in transgenic Arabidopsis [8], is transformed into the soybean genome. We obtain six transgenic lines with enhanced tolerance against $P$. sojae race 1 over three generations, compared with the wild-type plants. Furthermore, we observe an up-regulation of several defense-related genes in these transgenic lines. These observations indicate that CaAMP1 plays a functional role in stimulating defense-related genes involved in SA-dependent, JAdependent, and $R$-defense signaling in response to pathogenic infection.

SA- and JA-dependent signaling pathways are essential for defense against pathogens. SA is crucial to immune responses against biotrophic and hemibiotrophic pathogens $[30,31]$, and also involves in cross talks between ethylene and methyl jasmonate signaling pathways [32, 33]. SA-dependent defense pathways can be induced when pathogen infects the plant and finally activate on pathogenic infection in plants, subsequently activating the PRs [34]. Over-expression of CaAMP1 protein in Arabidopsis triggers rapid expression of AtPR1 and 


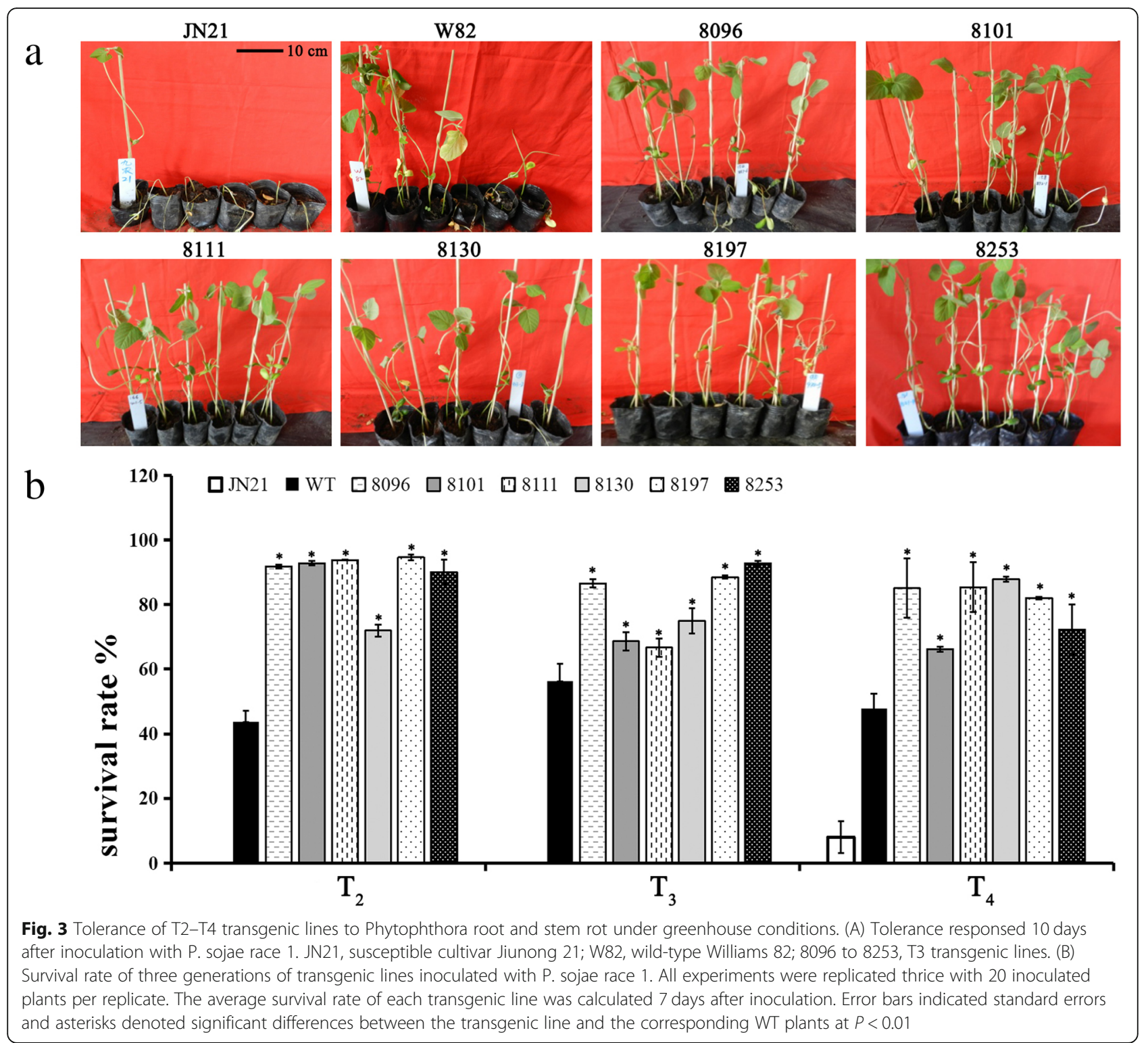

AtPR5 after infection with the virulent strain Pst DC3000, enhancing plant resistance to this disease [8]. In addition to $P R$ genes, three other SA-dependent pathways genes, i.e., $P A L, N P R 1-1$, and NPR1-2 are also upregulated in the CaAMP1 transgenic lines in the present study. $P A L$ is required in SA bio-synthesis pathways [35-37], and NPRs are indispensable for cross talks between SA and JA/ethylene responses [38]. Overexpression of these two genes can enhance disease tolerance in soybean and Arabidopsis [39, 40]. Furthermore, the activation of SA-dependent $P R$ genes is observed to be more rapid and intense in NPR1-OX transgenic plants than in their wild-type counterparts [40]. These genes can also be up-regulated in transgenic soybean by exogenous oxalate oxidase, $h r p Z m$, and $h r f 2$, after infection with $P$. sojae race $1[28,29,37]$.
JA-regulated defense is an important component of plant resistance to necrotrophic fungi [32, 41, 42]. AOS and $P P O$, involved in JA-dependent signaling pathway, are induced in CaAMP1-OX soybean lines. This is not consistent with the observations made in Arabidopsis [8], which may be attributed to the different genes selected in the present study. SGT1 and RAR1 are important genes in plant resistance signaling pathways [43-45], which are also up-regulated in CaAMP1-OX transgenic soybean.

Collectively, these results suggest that CaAMP1, as an AMP, can enhance PRR tolerance in transgenic soybean by triggering the production of SA- and JA-dependent defense signaling molecules and $R$-genes. These results confirm that rapid induction of SA and JA signaling pathways is associated with early recognition of the 


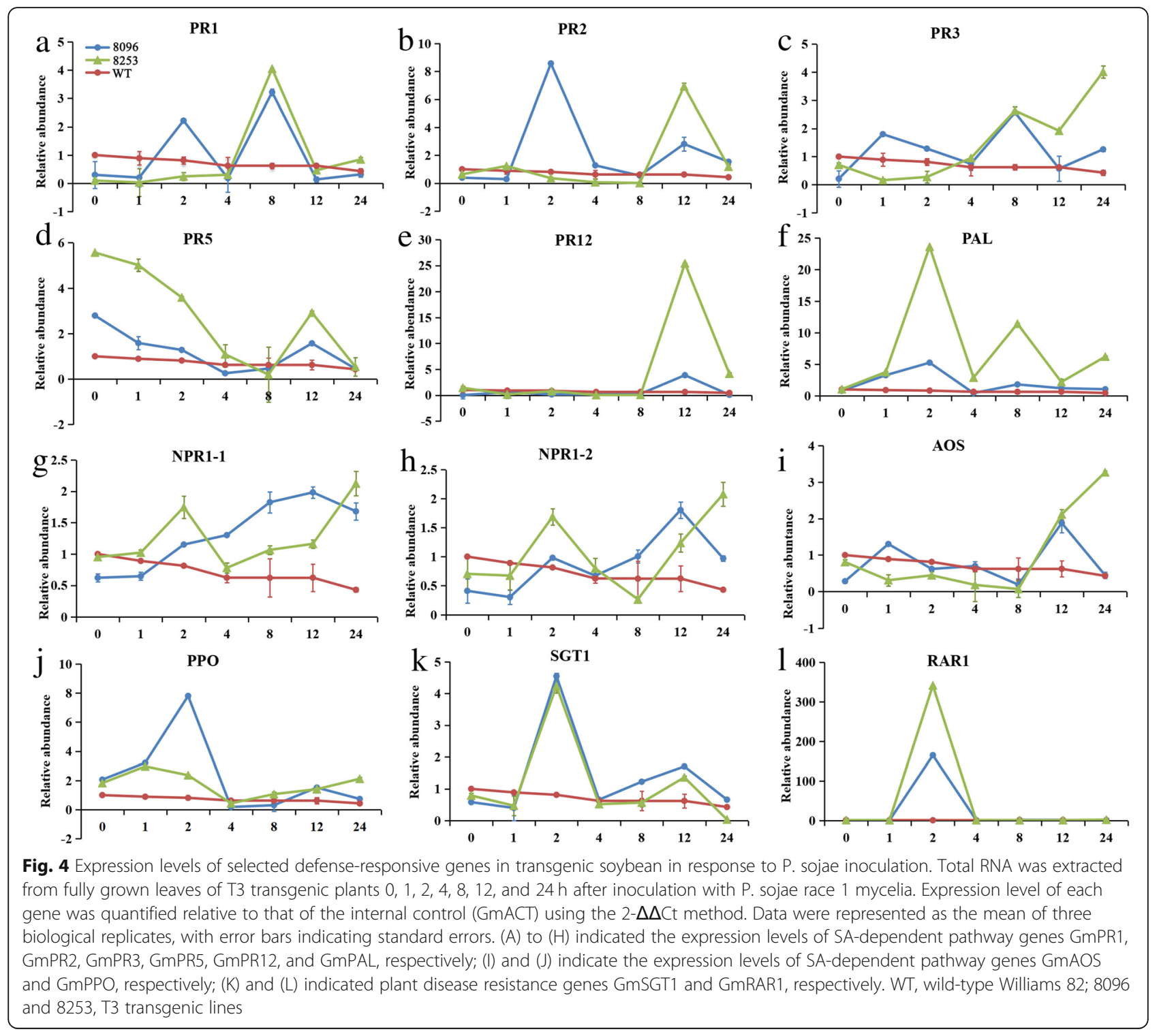

Table 1 Agronomic traits of CAAMP1-OX soybean in the fields

\begin{tabular}{llllllll}
\hline Phenotype & Williams 82 & 8096 & 8101 & 8111 & 8130 & 8197 & 8253 \\
\hline Maturity period (days) & 131 & 130 & 131 & 130 & 131 & 131 & 130 \\
Leaf shape & Round & Round & Round & Round & Round & Round & Round \\
Flower color & White & White & White & White & White & White & White \\
Hilum color & Black & Black & Black & Black & Black & Black & Black \\
Plant height (cm) & $97.76 \pm 4.40$ & $97.03 \pm 3.74$ & $97.00 \pm 4.10$ & $97.13 \pm 4.47$ & $96.84 \pm 2.87$ & $96.89 \pm 4.03$ & $97.19 \pm 2.64$ \\
Node number & $20.20 \pm 0.98$ & $20.15 \pm 1.01$ & $19.85 \pm 1.31$ & $20.25 \pm 1.04$ & $19.95 \pm 1.20$ & $20.1 \pm 0.94$ & $20.25 \pm 0.89$ \\
Branch number & $4.15 \pm 0.36$ & $4.20 \pm 0.40$ & $4.25 \pm 0.433$ & $4.25 \pm 0.433$ & $4.10 \pm 0.30$ & $4.30 \pm 0.46$ & $4.20 \pm 0.40$ \\
Podding height (cm) & $5.41 \pm 0.40$ & $5.49 \pm 0.41$ & $5.37 \pm 0.36$ & $5.35 \pm 0.36$ & $5.41 \pm 0.400$ & $5.41 \pm 0.32$ & $5.44 \pm 0.47$ \\
100-seed weight (g) & $18.91 \pm 0.93$ & $18.47 \pm 0.81$ & $18.27 \pm 0.57$ & $18.01 \pm 0.41$ & $18.13 \pm 0.39$ & $18.24 \pm 0.61$ & $18.19 \pm 0.59$ \\
\hline
\end{tabular}


pathogen and resistance in soybean [46]. Furthermore, we do not observe differences in the agronomic traits between CaAMP1-OX lines and their wild-type counterparts.

\section{Conclusions}

The results of the present study indicated that overexpression of CaAMP1 in soybean can significantly enhance PRR tolerance by inducing the expression of resistant genes involved in multiple defense signaling pathways. This may provide an alternative approach for developing soybean varieties with improved tolerance against soil-borne pathogenic PRR.

\section{Methods}

\section{CaAMP1 synthesis and vector construction}

The nucleotide sequence of $C$. annuum CaAMP1 (GenBank ID: AAT35532.1) was synthesized with added Xba I and Sac I recognition sites at the $5^{\prime}$ and 3' ends, respectively (Sangon Biotech, Shanghai, China). The modified CaAMP1 gene was inserted into a pCambia3300 vector containing a modified $C a M V 35 S$ promoter [47] (GenBank: GI3319906) to facilitate its constitutive expression in soybean. The gene sequence was amplified using the CaAMP1-F/R primer pair, with a final primer concentration of $0.4 \mu \mathrm{M}$, under the following conditions: $94{ }^{\circ} \mathrm{C}$ for $5 \mathrm{~min}$; followed by $35 \mathrm{cycles}$ of $94^{\circ} \mathrm{C}$ for $30 \mathrm{~s}$, $59^{\circ} \mathrm{C}$ for $30 \mathrm{~s}$, and $72{ }^{\circ} \mathrm{C}$ for $30 \mathrm{~s}$; and final extension at $72^{\circ} \mathrm{C}$ for $7 \mathrm{~min}$. All primers used in this study were listed in Table S1. The purified fragment was then subcloned into a pCambia3300 plasmid containing a phosphinothricin acetyl transferase (bar) resistance gene, encoding PAT, as a plant selection marker driven by a modified CaMV $35 \mathrm{~S}$ promoter [47] (GenBank: GI3319906). The constructed pCambia3300-CaMV 35SCaAMP1 plasmid was subsequently transformed into competent $A$. tumefaciens strain EHA101 cells, by the freeze-thaw method $[48,49]$.

\section{Regeneration and screening of transgenic plants}

Agrobacterium-mediated transformation was used for regenerating transgenic soybean, with the soybean cultivar Williams 82 as the recipient, which was provided by Prof. Fudi Xie of Shenyang Agricultural University, China (ID: WDD00587, Chinese Crop Germplasm Information System, http://www.cgris.net), following the method described in Yang et al. (2018) and Zhang et al. (2014) [50, 51]. The regenerated PAT-tolerant plants were screened using LibertyLink ${ }^{\bullet}$ strip test (cat \#AS 013 LS; EnviroLogix Inc., Portland, ME, USA) and PCR. Herbicide-tolerant $T_{1}-T_{3}$ transgenic lines were identified by spraying the leaves with $500 \mathrm{mg} \cdot \mathrm{L}^{-1}$ glufosinate (EnviroLogix Inc., Portland, Maine, USA) on complete expansion of the first trifoliate leaves, and then analyzed by PCR using the CaAMP1-F1/R1 and Bar-F/R primer pairs (Table S1) until homozygous transgenic plants were obtained. DNA was extracted from the leaves of transgenic and wild-type soybean, using a simple homogenization and ethanol precipitation method, for PCR analysis [52]. PCR was performed with a final primer concentration of $0.2 \mu \mathrm{M}$, with the following conditions: $94{ }^{\circ} \mathrm{C}$ for $5 \mathrm{~min}$; followed by 35 cycles of $94{ }^{\circ} \mathrm{C}$ for $30 \mathrm{~s}, 58^{\circ} \mathrm{C}$ for $30 \mathrm{~s}$, and $72{ }^{\circ} \mathrm{C}$ for $30 \mathrm{~s}$; and final extension at $72{ }^{\circ} \mathrm{C}$ for $7 \mathrm{~min}$.

To confirm the integration of T-DNA in transgenic soybean, $\mathrm{T}_{2}$ transgenic plants were selected for genomic DNA extraction, using a modified high salt cetyltrimethyl ammonium bromide method [53]. DIG High Prime DNA Labeling and Detection Starter Kit I (No. 11745832910; Roche Applied Science, Indianapolis, IN, USA) was used for Southern blot analysis, according to the manufacturer's instructions. Approximately $30 \mu \mathrm{g}$ of the genomic DNA from transgenic soybean and control plants was digested completely with EcoR I (New England Biolabs Inc., Beverly, Massachusetts). The digested DNA was then transferred onto positively charged nylon membranes (GE Amersham, RPN303B, USA). Hybridization was carried out at $42{ }^{\circ} \mathrm{C}$ for $12-16 \mathrm{~h}$, using CaAMP1 labeled with digoxigenin-(DIG)11-dUTP as a probe. The washing conditions and signal detection were as described in Yang et al. (2018) [50].

\section{Expression analysis in transgenic soybean}

Total RNA and proteins were extracted for expression analysis. Total RNA was extracted from 2-week-old leaves of $\mathrm{T}_{3}$ transgenic plants $(8096,8101,8111,8130$, 8197, 8253) using a EasyPure PlantRNA Kit (TransGen Biotech, Beijing, China), and DNase I was used to eliminate the contaminant genomic DNA. cDNA was then synthesized using the ThermoScript RT-PCR system (Invitrogen, USA), and RT-PCR was performed using CaAMP-RF/RR primers (Table S1). GmACT (GeneBank ID: NM 001289231), amplified using the primers 5'CACCGGAGTTTTCACCGATA-3' and 5' ${ }^{\prime}$-AGGAAT GATGTTAA-3', was used as the control.

Crude proteins were extracted from $\sim 100 \mathrm{mg}$ fresh leaves of the control and $\mathrm{T}_{3}$ transgenic soybean lines (8096, 8101, 8111, 8130, 8197, 8253), separated on a $12 \%$ $(\mathrm{w} / \mathrm{v})$ SDS-PAGE gel, and then transferred electrophoretically onto a PVDF membrane (Amersham ${ }^{\mathrm{m}}$ Hybond $^{\mathrm{Tm}}$, GE Healthcare, USA) [54]. After blocking with $3 \%$ dried skimmed milk diluted in PBST $(1 \times$ PBS, $0.1 \%$ Tween20 ), the membrane was blotted with a rabbit polyclonal antibody (1:500 dilution) raised against recombinant CaAMP1 protein (GenScript Co., Ltd. Nanjing, China) and horseradish peroxidase (HRP)-labeled goat-antirabbit IgG (1:5000 dilution; Abcam, UK) at $25^{\circ} \mathrm{C}$ for $4 \mathrm{~h}$. The bands observed following western blotting were 
visualized using the BiodlightTM Western Chemiluminescent HRP substrate (Bioworld Technology, Inc., St. Louis, MN, USA) after extensive washing.

Evaluation of PRR tolerance under greenhouse conditions To evaluate the tolerance of transgenic soybean against $P$. sojae race 1 , the $\mathrm{T}_{2}-\mathrm{T}_{4}$ generations of transgenic lines 8096, 8101, 8111, 8130, 8197, and 8253 were infected with $P$. sojae race 1 , following the method described by Schmitthenner et al. (1994) [55]. Isolation and cultivation of the inoculum were performed as described by Akamatsu et al. (2010) and Du et al. (2018) $[28,56]$. Transgenic soybean, wild-type Williams 82 , and the PRR-susceptible cultivar Jiunong 21 (ID:ZDD22796), which were provided by the Soybean Research Institute of Jilin Academy of Agricultural Sciences, were grown in a greenhouse, and the hypocotyls of 15-day-old seedlings were inoculated with macerated mycelia of $P$. sojae race 1 . The plants were then maintained in a humid environment for $15-24 \mathrm{~h}$, before being transferred to the greenhouse for symptom development, at $25^{\circ} \mathrm{C}$ under an 18 -h light/6-h dark photoperiod [28]. After 5 to 10 days of inoculation, plant infection data were collected and survival rates were calculated [57]. All experiments were performed with three replicates of 20 inoculated plants each replicate.

Differences in the survival rates of the control and transgenic lines were quantitatively assessed by $t$-test at a significance level of $P=0.05$ or 0.01 , using Microsoft Analysis Tool.

Quantitative RT-PCR analysis of disease-responsive genes Leaves were collected from $\mathrm{T}_{3}$ transgenic lines (8096 and 8253) and wild-type Williams 82 plants, 0, 1, $2,4,8,12$, and $24 \mathrm{~h}$ after inoculation with $P$. sojae race 1 mycelia, for quantitative PCR. Total RNA extraction and cDNA synthesis were performed as described in previous sections. The relative expression levels of 12 genes involved in different stress response pathways, including GmPR1 (AF136636), GmPR2 (M37753), GmPR3 (AF202731), GmPR5 (BU765509), GmPR12 (BU964598), GmPAL (X52953), GmPPO (EF158428), GmAOS (DQ288260), GmSGT1 (NM_001249656), GmNPR1-1 (FJ418594), GmNPR1-2 (FJ418596), and GmRAR1 (FJ222386), were analyzed by qRT-PCR, with GmACT (U60500) as the internal control. Amplification was performed in a final reaction volume of $20 \mu \mathrm{L}$, with $\sim 80 \mathrm{ng}$ cDNA and $0.4 \mu \mathrm{L}$ each of forward and reverse primers (Table S1), using a SYBR Green-based One-Step qRTPCR kit (TransGen Biotech, China). The conditions for the qRT reaction were as follows: $50{ }^{\circ} \mathrm{C}$ for $2 \mathrm{~min}$; $95^{\circ} \mathrm{C}$ for $10 \mathrm{~min}$; and 45 cycles of $95^{\circ} \mathrm{C}$ for $2 \mathrm{~min}, 62^{\circ} \mathrm{C}$ for 30 $\mathrm{s}$, and $72^{\circ} \mathrm{C}$ for $30 \mathrm{~s}$. The relative expression level of each gene was determined using the $2^{-\Delta \Delta \mathrm{Ct}}$ method [58].
To improve the accuracy of the data, three biological and three technical replicates were performed for each experiment.

\section{Agronomic traits of transgenic lines}

Nine agronomic traits of $\mathrm{T}_{3}$ transgenic lines and wildtype soybean were assessed, including maturity period, leaf shape, plant height, flower color, hilum color, branch number, node number, podding height, and 100seed weight, and $t$-test was used for quantitative analysis.

\section{Supplementary information}

Supplementary information accompanies this paper at https://doi.org/10. 1186/s12863-020-00872-0.

Additional file 1. Supplementary Table 1

\section{Abbreviations}

CaAMP1: Capsicum annuum antimicrobial protein 1; PRR: Phytophthora root and stem rot; SA: Salicylic acid; JA: Jasmonic acid; AMPs: Antimicrobial peptides; PR: Pathogenesis-related; OsDEF7: Oryza sativa defensin 7 ; OsDEF8: Oryza sativa defensin 8; OX: Over-expression; CaMV 35s: Cauliflower mosaic virus $35 \mathrm{~S}$ promoter; PCR: Polymerase chain reaction;

PAT: Phosphinothricin N-acetyltransferase; EDTA: Ethylene diamine tetraacetic acid; SDS: Sodium dodecyl sulfonate; PVDF: Polyvinylidene fluoride; PBST: Phosphate buffered solution with Tween-20; HRP: Horseradish peroxidase; PAL 1: Phenylalanine ammonia lyase 1; PPO: Polyphenol oxidase; AOS: Allene oxide synthase; SGT1: Suppressor-of-G2-allele-of-skp 1; NPR1: Nonexpressor of pathogenesis-related gene 1; RAR1: Required for Mla12-mediated resistance 1; ACT : Actin; RT: Reverse transcript

\section{Acknowledgements}

We thank Prof. Fudi Xie for kindly providing the wild-type Williams 82 seeds. We are also grateful to the Soybean Research Institute, Jilin Academy of Agricultural Sciences, for providing the soybean cultivar Jiunong 21. We would like to thank Editage (www.editage.cn) for English language editing.

\section{Authors' contributions}

YSD and XDY designed the experiments. LN and XFZ analyzed the data and drafted the manuscript. YYZ, JY, GJX, and RM performed the experiments. DBL acquired the experimental plant materials. All authors contributed to manuscript revision and have approved the final version.

\section{Funding}

This work was supported by grants from the Jilin Provincial Agricultural Science \& Technology Innovation Project (CXGC2017JQ013, CXGC2017ZY029), National Natural Science foundation of China (31701448), and China National Novel Transgenic Organisms Breeding Project (2016ZX08004-004). These funds helped purchase experimental reagents and consumables as well as facilitated services for preparing manuscript.

\section{Availability of data and materials}

All datasets used and/or analyzed in this study are available from the corresponding authors on reasonable request.

Ethics approval and consent to participate Not applicable.

Consent for publication

Not applicable.

Competing interests

The authors declare that they have no competing interests. 


\section{Author details}

'Jilin Provincial Key Laboratory of Agricultural Biotechnology, Jilin Academy of Agricultural Sciences, Changchun 130033, China. ${ }^{2}$ Jilin Normal University, Siping 136000, China.

Received: 14 November 2019 Accepted: 19 June 2020 Published online: 06 July 2020

\section{References}

1. Nawrot R, Barylski J, Nowicki G, Broniarczyk J, Buchwald W, Goździcka-Józefiak A. Plant antimicrobial peptides. Folia Microbiol (Praha). 2014;59:181-96.

2. Yount NY, Yeaman MR. Peptide antimicrobials: cell wall as a bacterial target. Ann N Y Acid Sci. 2013;1277:127-38.

3. DeGray, Gajasekaran RK, Smith F, Sanford J, Daniell H. Expression of an antimicrobial peptide via the chloroplast genome to control phytopathogenic bacteria and fungi. Plant Physiol. 2001;127:852-862.

4. Selitrennikoff C. Antifungal proteins. Appl Environ Microbiol. 2001;67:2883-94.

5. Shatters RG Jr, Boykin LM, Lapointe SL, Hunter WB, Weathersbee AA 3rd. Phylogenetic and structural relationships of the PR5 gene family reveal an ancient multigene family conserved in plants and select animal taxa. J Mol Evol. 2006;63:12-29.

6. Chisholm ST. Coaker G, day Brad, Staskawicz BJ. Host-microbbe interactions: shaping the evolution of the plant immune response. Cell. 2006;124:803-14.

7. Tantong S, Pringsulaka O, Weerawanich K, Meeprasert A, Rungrotmongkol T, Sarnthima R, Roytrakul S, Sirikantaramas S. Two novel antimicrobial defensins from rice identified by gene coexpression network analyses. Peptides. 2016;84:7-16.

8. Lee SC, Hwang IS, Choi HW, Hwang BK. Involvement of the pepper antimicrobial protein CaAMP1 gene in broad spectrum disease resistance. Plant Physiol. 2008;148:1004-20.

9. Weerawanich K, Webster G, Ma J, Phoolcharoen W, Sirikantaramas S. Gene expression analysis, subcellular localization, and in planta antimicrobial activity of the rice (Oryza sativa L.) defensin 7 and 8. Plant Physiol Biochem. 2018;124:160-6.

10. Wang YP, Wei ZY, ZhangYY, Lin CJ, Zhong XF, Wang YL, Ma JY, Ma J, Xing SC. Chloroplast-expressed MSI-99 in tobacco improves disease resistance and displays Inhibitory effect against rice blast fungus. Int J Mol Sci. 2015;16: 4628-4641.

11. Gao AG, Hakimi SM, Mittanck CA, Wu Y, Woener BM, Stark DM, Shah DM, Liang J, Rommens CM. Fungal pathogen protection in potato by expression of a plant defensin peptide. Nat Biotechnol. 2000;10:1307-10.

12. Zhou M, Hu Q, Li ZG, Li DY, Chen CF, Luo H. Expression of a novel antimicrobial peptide Penaeidin4-1 in creeping bentgrass (Agrostis stolonifera L.) enhances plant fungal disease resistance. PLoS One. 2011;6: e24677.

13. Inui Kishi RN, Stach-Machado D, Singulani JL, Dos Santos CT, Fusco-Almeida AM, Cilli EM, Freitas-Astúa J, Picchi SC, Machado MA. Evaluation of cytotoxicity features of antimicrobial peptides with potential to control bacterial diseases of citrus. PLoS One. 2018;13(9):e0203451.

14. Kumar M, Yusuf MA, Yadav P, Narayan S, Kumar M. Overexpression of chickpea defensin gene confers tolerance to water-deficit stress in Arabidopsis thaliana. Front Plant Sci. 2019;10:290.

15. Tyler BM. Phytophthora sojae: root rot pathogen of soybean and model oomycete. Mol Plant Pathol. 2007:8:1-8.

16. Lin F, Zhao M, Ping J, Johnson A, Zhang B, Abney TS, Hughes TJ, Ma J. Molecular mapping of two genes conferring resistance to Phytophthora sojae in a soybean landrace pi 567139b. Theor Appl Genet. 2013;126:2177-85.

17. Shen CY, Sun Y. Discovery and preliminary studies of phytophora megasperma on soybean in China (in chinese). Acta Phytopathologica Sin. 1991;21:298.

18. Zuo Y, Xue C, Han W, Liu T. The infections characteristics of Phytophthora sojae to soybean seedlings (in chinese). Acta Phytophylacica Sin. 2002;12: 377-8.

19. Zhao X, Sun M, Han Y, Li X, Zhang H, Teng W, Li W. Identification of loci underlying tolerance to Phytophthora root rot in soybean germplasm (in chinese). Soybean Sci. 2014;33:488-91.

20. Sugimoto K, Fujita S, Miyazawa T, Nishi H, Okada M, Takemura T. Pediatric left renal vein entrapment syndrome diagnosed by 99mtc-albuminconjugate scintigraphy. Nephron Clin Pract. 2012;122:122-6.

21. Sugimoto T, Kato M, Yoshida S, Matsumoto I, Kobayashi T, Kaga A, Hajika M, Yamamoto R, Watanabe K, Aino M, et al. Pathogenic diversity of
Phytophthora sojae and breeding strategies to develop Phytophthoraresistant soybeans. Breed Sci. 2012;61:511-22.

22. Sun S, Zhao S, Wang JM, Zhao JM, Wang YC, Tang QH, Yu DY, Gai JY, Xing $\mathrm{H}$. Characterization and mapping of RpsYu25, a novel resistance gene to Phytophthora sojae. Plant Breed. 2011;130:139-43.

23. Sun JT, Li LH, Zhao JM, Huang J, Yan Q, Xing H, Guo N. Genetic analysis and fone mapping of RpsJS, a novel resistance gene to Phytophthora sojae in soybean [Glycine max (L.) Merr.]. Theor Appl Genet. 2014;127:913-9.

24. Wu XL, Zhang BQ, Sun S, Zhao JM, Yang F, Guo N, Hai JY, Xing H. Identification, genetic analysis and mapping of resistance to Phytophthora sojae of Pm28 in soybean. Theor Appl Genet. 2013;126:1555-61.

25. Zhang JQ, Xia JC, Duan CX, Sun SL, Wang XM, Wu XF, Zhu ZD. Identification and candidate gene analysis of a novel phytophthora resistance gene Rps10 in a Chinese soybean cultivar. PLoS One. 2014;8:e69799.

26. Burnham K. Quantitative trait loci for partial resistance to Phytophthora sojae in soybean. Crop Sci. 2003:43:1610-7.

27. Fan S, Jiang L, Wu J, Dong L, Cheng Q, Xu P, Zhang S. A novel pathogenesis-related class 10 protein gly $\mathrm{m} 4 \mathrm{l}$, increases resistance upon Phytophthora sojae infection in soybean (Glycine max [L.] Merr.). PloS ONE. 2015;e0140364.

28. Du Q, Yang XD, Zhang JH, Zhong XF, Kim KS, Yang J, Xing GJ, Li XY, Jiang $Z Y$, Li QY, et al. Over-expression of the Pseudomonas syringae harpinencoding gene hrpZm confers enhanced tolerance to Phytophthora root and stem rot in transgenic soybean. Transgenic Res. 2018;27:277-88.

29. Niu L, Yang J, Zhang JH, He HL, Xing GJ, Zhao QQ, Guo DQ, Sui L, Zhong $X F$, Yang XD. Introduction of the harpinXooc-encoding gene hrf2 in soybean enhances resistance against the oomycete pathogen Phytophthora sojae. Transgenic Res. 2019;28:257-66.

30. Shah J. The salicylic acid loop in plant defense. Curr Opin Plant Biol. 2003;6: 365-71.

31. Howe GA, Jander G. Plant immunity to insect herbivores. Annu Rev Plant Biol. 2008:59:41-66.

32. Veronese P, Chen X, Bluhm B, Salmeron J, Dietrich R, Mengiste T. The BOS loci of Arabidopsis are required for resistance to Botrytis cinerea infection. Plant J. 2004;40:558-74.

33. Liu G, Holub E, Alonso JM, Ecker JR, Fobert PR. An Arabidopsis NPR1-like gene, NPR4, is required for disease resistance. Plant J. 2005:41:304-18.

34. Belles JM, Garro R, Fayos J, Navarro P, Primo J, Conejero V. Gentisic acid as a pathogen-inducible signal, additional to salicylic acid for activation of plant defenses in tomato. Mol Plant-Microbe Interact. 1999;12:227-35.

35. Lyne RL, Mulheirn LJ, Leworthy DP. New pterocarpinoid phytoalexins of soybean. J. Chem Soc Chem Commun. 1976;13:497-8.

36. Dixon RA, Achnine L, Kota P, Liu CJ, Reddy MS, Wang L. The phenylpropanoid pathway and plant defence a genomics perspective. Mol Plant Pathol. 2002;3:371-90.

37. Vlot AC, Dempsey DA, Klessig DF. Salicylic acid, a multifaceted hormone to combat disease. Annu Rev Phytopathol. 2009;47:177-206.

38. Backer R, Naidoo S, van den Berg N. The nonexpressor of pathogenesisrelated gene 1 (NPR1) and related family:mechanistic insights in plant disease resistance. Front Plant Sci. 2019;10.

39. Zhang CZ, Wang X, Zhang F, Dong LD, Wu JJ, Cheng Q, Qi DY, Yan XF, Jiang LY, Fan SJ, et al. Phenylalanine ammonia-lyase2.1 contributes to the soybean response towards Phytophthora sojae infection. Sci Rep. 2017;7:7242.

40. Cao H, Li X, Dong X. Generation of broad-spectrum disease resistance by overexpression of an essential regulatory gene in systemic acquired resistance. Proc Natl Acad Sci U S A. 1998;95:6531-6.

41. van Wees SC, Chang HS, Zhu T, Glazebrook J. Characterization of the early response of Arabidopsis to Alternaria brassicicola infection using expression profiling. Plant Physiol. 2003;132:606-17.

42. Coego A, Ramirez V, Gil MJ, Flors V, Mauch-Mani B, Vera P. An Arabidopsis homeodomain transcription factor, OVEREXPRESSOR OF CATIONIC PEROXIDASE 3, mediates resistance to infection by necrotrophic pathogens. Pant Cell. 2005;17:2123-37.

43. Azevedo C, Sadanandom A, Kitagawa K, Freialdenhoven A, Shirasu K, Schulze-Lefert $P$. The RAR1 interactor SGT1, an essential component of $R$ gene-triggered disease resistance. Science. 2002;295:2073-6.

44. Tör M, Gordon P, Cuzick A, Eulgem T, Sinapidou E, Mert-Türk F, Can C, Dang $J L$, Holub EB. Arabidopsis SGT1b is required for defense signaling conferred by several downy mildew resistance genes. Plant Cell. 2002;14:993-1003.

45. Peart JR, Lu R, Sadanandom A, Malcuit I, Moffett P, Brice DC, Schauser L, Jaggard DA, Xiao S, Coleman MJ, et al. Ubiqutin ligase-associated protein 
SGT1 is required for host and nonhost disease resistance in plants. Proc Natl Acad Sci U S A. 2002;99:10865-9.

46. Ranjan A, Westrick NM, Jain S, Piotrowski JS, Ranjan M, Kessens RL, Stiegman L, Grau CR, Conley SP, Smith DL, et al. Resistance against Sclerotinia sclerotiorum in soybean involves a reprogramming of the phenylpropanoid pathway and up-regulation of antifungal activity targeting ergosterol biosynthesis. Plant Biotechnol J. 2019;17:1567-81.

47. Hardegger M, Brodmann P, Herrmann A. Quantitative detection of the 355 promoter and the NOS terminator using quantitative competitive PCR. European Food Research Technology. 1999;209:83-7.

48. Holsters M, de Waele D, Depiker A, Messens E, Van Montagu M, Schell J. Transfection and transformation of Agrobacterium tumefaciens. Mol Gen Genet. 1978;163:181-7.

49. Nishiguchi R, Takanami M, Oka A. Characterization and sequence determination of the replicator region in the hairy-root-inducing plasmid pRiA4b. Mol Gen Genet. 1987;206:1-8.

50. Yang J, Xing GJ, Niu L, He HL, Guo DQ, Du Q, Qian XY, Yao Y, Li HY, Zhong $X F$, et al. Improved oil quality in transgenic soybean seeds by RNAimediated knockdown of GMFAD2-1B. Transgenic Res. 2018;27:155-66.

51. Zhang L, Yang XD, Zhang YY, Yang J, Qi GX, Guo DQ, Xing GJ, Yao Y, Xu WJ, Li HY, et al. Changes in oleic acid content of transgenic soybeans by antisense RNA-mediated posttranscriptional gene silencing. Int J Genomics. 2014;921950.

52. Edwards K, Johnstone C, Thompson C. A simple and rapid method for the preparation of plant genomic DNA for PCR analysis. Nucleic Acids Res. 1991; 19:1349.

53. Tel-zur N, Abbo S, Myslabodski D, Mizrahi Y. Modified CTAB procedure for DNA isolation from epiphytic cacti of the genera Hylocereus and Selenicereus (Cactaceae). Plant Mol Biol Report. 1999;17:249-54.

54. Yang X, Yang J, Wang Y, He H, Niu L, Guo D, Xing G, Zhao Q, Zhong X, Sul $L$, et al. Enhanced resistance to sclerotinia stem rot in transgenic soybean that overexpresses a wheat oxalate oxidase. Transgenic Res. 2019;28:103-14.

55. Schmitthenner AF, Hobe M, Bhat RG. Phytophthora sojae races in Ohio over 10-year interval. Plant Dis. 1994;78:269-76.

56. Akamatsu A, Chilvers M, Stewatr J, Peever T. Identifacation and function of a polyketide synthase gene responsible for 1,8-dihydroxynaphthalene-melanin pigment biosynthesis in Ascochyta rabiei. Curr Genet. 2010;56:349-60.

57. Zhu ZD, Wang XM. An identification method of soybean resistance to phytophthora root rot (in chinese). Chinese J Oil Crop Sci. 1999;21:52-4.

58. Livak KJ, Schmittgen TD. Analysis of relative gene expression data using real-time quantitative $P C R$ and the 2(-Delta Delta $C(T))$. Method Methods. 2001;25:402-8

\section{Publisher's Note}

Springer Nature remains neutral with regard to jurisdictional claims in published maps and institutional affiliations.

Ready to submit your research? Choose BMC and benefit from:

- fast, convenient online submission

- thorough peer review by experienced researchers in your field

- rapid publication on acceptance

- support for research data, including large and complex data types

- gold Open Access which fosters wider collaboration and increased citations

- maximum visibility for your research: over $100 \mathrm{M}$ website views per year

At $\mathrm{BMC}$, research is always in progress.

Learn more biomedcentral.com/submissions 